\title{
A Genre-Based Approach to Writing Instruction in EFL Classroom Contexts
}

\author{
Akiko Nagao ${ }^{1}$ \\ ${ }^{1}$ Faculty of International Studies, Ryukoku University, Kyoto, Japan \\ Correspondence: Akiko Nagao, Faculty of International Studies, Ryukoku University, 67 Tsukamoto-cho, \\ Fukakusa, Fushimi-ku, Kyoto, Japan. Tel: 075-642-1111. E-mail: nagao@world.ryukoku.ac.jp
}

Received: March 20, 2018

Accepted: April 22, 2018 Online Published: April 24, 2018

doi: $10.5539 /$ elt.v11n5p130

URL: http://doi.org/10.5539/elt.v11n5p130

\begin{abstract}
This study explored how 14 foreign-language writers at a university in Japan changed their genre awareness of discussion genre texts (particularly argumentative essays) during a 15 -week systemic functional linguistics course consisting of text-based writing lessons assigned as part of a teaching and learning cycle. To obtain in-depth quantitative and qualitative insights into changes in the students' awareness of genre and writing skills, pre- and post-surveys and self-reflection written texts were administered and analyzed. Twelve previously proposed criteria (covering generic structure, lexicogrammar, and multidimensional analyses of attitudes and performance) were used to analyze the self-reflection texts. The preliminary results showed that the students' understanding of generic structure and lexicogrammar improved, especially their comprehension of the second and third paragraphs of the target genre text. The preliminary results of the correlation analysis illustrated that the increased understanding of lexicogrammatical features, such as textual meaning, interpersonal meaning, and experiential meaning, was related to their self-efficacy and confidence in their writing skills. The preliminary analysis results indicated that that applying a teaching and learning cycle and a genre-based approach to writing instruction has the potential to enhance EFL students' awareness of generic structure and interpersonal meaning in writing argumentative essays.
\end{abstract}

Keywords: EFL writing proficiency, longitudinal study, EFL genre-based approach to learning, teaching and learning cycle

\section{Introduction: The Genre-Based Approach to Language Learning}

The product approach to writing, frequently used since 1960, emphasizes accuracy of form based on the idea that learning is the product of forming habits (Silva, 1990). In 1980, the process approach (Flower \& Hayes, 1981) to writing was expanded to include the concept of the product approach (Jordan, 1997). The process approach focuses on the writer, specifically on the creative thinking that demonstrates the non-linear process that a writer uses when writing. Although previous approaches emphasize the form of language, the process approach focuses on writers and pays less attention to readers (Silvia, 1991). The process approach centers on the writer's thoughts and focuses on the importance of repeated thinking. Writing as a recursive process, however, does not reflect the writer's socio-cultural characteristics. In the 1990s, the genre-based approach evolved as a reaction to the weaknesses of the process approach. In learning to understand generic texts, students begin to recognize the generic patterns and related language features they encounter within texts (L. Price \& J. Price, 2002). In the genre approach, clear instruction is used to explain the linguistic characteristics and rhetorical patterns specific to the discourse in which students seek to participate (Hyland, 2004, 2007), thereby teaching the purposes, structures, and language features of genres.

In the context of Japanese undergraduate and graduate schools, the genre-based approach is a rarely used method for teaching English writing (Rajagopalan \& Jie, 2016; Yasuda, 2015). The aim of this paper is to share with fellow EFL teachers the results of an exploration of the use of SFL-based teaching methods in the EFL learning context. EFL students are expected to learn how to identify and use appropriate lexicogrammar in order to become effective writers. The current study examined developments in genre awareness, generic structures, and lexicogrammatical choices over the course of one semester, among students in an English for academic purposes (EAP) class conducted at a Japanese university. 


\section{Literature Review}

\subsection{Learning Language in the Context of Systemic Functional Linguistics}

Systemic functional linguistics (SFL) is a linguistic theory that clarifies the relationship between social context and linguistic phenomena (Halliday 1994; Schleppegrell, 2004). Language as a theory of experience, according to SFL, suggests that understanding language defines understanding how this learning happens (Halliday, 1994; Halliday \& Hasan, 1989; Schleppegrell, 2004). Languages are shaped by their users, individual writers and speakers, in social contexts (Schleppegrell, 2004). In other words, the concept of SFL emphasizes the social nature of language and language use (Steiner, 1997); language is used and situated in its relationship with the social context of the target language. To explain the relationship between language and context based on SFL, the notion of register is used to define the disposition of lexical and grammatical features in the involved situation (Halliday \& Hasan, 1989).

A register has three elements: field, tenor, and mode. The purpose of a field is to present ideas, ideational choices, and ideational meaning. As a category, it also covers the lexical and grammatical choices of writers and speakers, such as noun phrases, nominal groups, verbs (process types), place, manner, and resources for establishing logical relationships (Halliday, 1994; Schleppegrell, 2004). The tenor of a text indicates what type of relationship exists between the writer and his or her readers (Halliday, 1994), and analyzing the lexical and grammatical features of written texts enables the understanding of interpersonal choices and interpersonal meanings; that is, modality (modal verbs and adverbs) and mood (statements, questions, demands) (Schleppegrell, 2004). In terms of textual choice or textual meaning, analyzing mode has revealed information about how particular text types should be organized (Halliday, 1994; Schleppegrell, 2004). Understanding elements such as cohesive devices (i.e., conjunctions and connectors) and thematic organization enables the understanding of textual meaning (Schleppegrell, 2004). Thus, it is essential to use target genre texts that are relevant to students' social practices, because such learning "is a process of students' socialisation in making meanings with texts, intentionally building students' discourse resources for taking part in acts of meaning in society" (Mickan \& Lopez, 2017, p. 23).

\subsection{Target Genre in This Research: Discussion Essay Genre}

The target genre in this research was the discussion essay, also known as the "argumentative essay." The purpose of this genre is to present different opinions or perspectives on a specific issue (https://www.sac.sa.edu.au/Library/Library/Topics/Literacy/discussion.htm). The structure of a typical discussion essay is as follows: in the first paragraph, the topic and issues are addressed; in the second and third paragraphs, arguments for and against the major issue are introduced; and, in the final paragraph, the writer explains his or her opinion on the issue (UNSW Department of School Education, 1989). The writer of a discussion essay must choose appropriate language features to clarify his or her meaning. Experiential meaning, indicating material, relational, and mental processes, relies on the use of action verbs such as give, come, save, and find; verbal verbs such as state, claim, and assert; and mental verbs such as think, feel, and disagree. Interpersonal meanings are communicated through the use of modal verbs such as will, can, and could. In addition, adverbs such as absolutely, definitely, generally, and usually serve to control levels of emphasis and certainty. Finally, contrastive conjunctions such as on the other hand, however, conversely, and in contrast are used in composing the essay.

\subsection{Adapting an SFL-oriented Approach to the Particular Cultural-pedagogical Context}

In this study, an SFL-oriented, genre-based approach to writing was devised as the principal teaching methodology. As illustrated in Figure 1, English-language education in Japan has always been a bottom-up system where students are expected to learn target vocabulary and grammar (Nishijo, 2017). In high school, EFL students tend to focus heavily on grammar, translation, spelling, and reading long passages in order to pass their university entrance examinations (Matsumoto, 2015; McKinley, 2010). The SFL-based English writing classes that were the focus of the current research, on the other hand, employed a top-down system in which lexicogrammatical resources were chosen according to the goal of linguistic activity (Nishijo, 2017). According to Nishijo (2017), to choose suitably goal-oriented lexicogrammatical resources, it is necessary to understand the characteristics of each such resource. Because English education in Japan already places great importance on this, it is possible to build on it as a foundation (Nishijo, 2017). In SFL, language and position are considered a resource; language and its use are viewed not in terms of the correctness of usage relative to grammatical rules, but rather how social activity is expressed in language and how language is shaped by social activity (Halliday, Matthiessen, \& Matthiessen, 2014). Genre texts, especially those that are authentic, provide students with opportunities to create meaning that relates specifically to their participation in sociocultural practices (Mickan \& Lopez, 2017), and to learn appropriate lexicogrammatical choices through the SFL genre-based approach to 
learning as they engage in writing tasks.
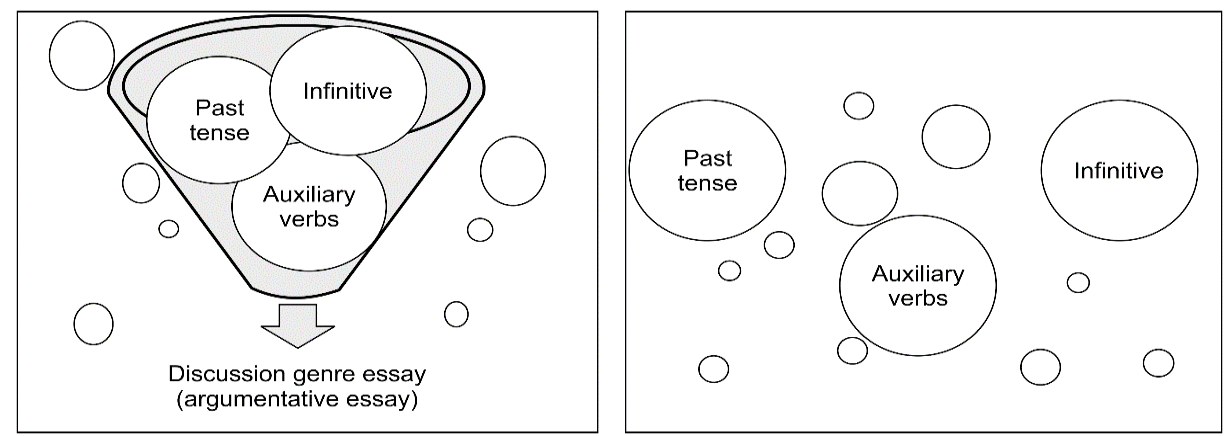

Figure 1. An SFL-oriented approach compared with the traditional approach

Note. A genre-based approach in which students choose vocabulary and semiotic resources relevant to genre purposes (on the left) compared with the traditional grammar-based teaching employed in Japan (on the right). Adapted from Nishijo (2017, p. 261) and the author modified it.

\subsection{Previous Research on SFL and Writing in EFL Contexts in Japan}

Numerous studies have investigated various areas and types of SFL-based writing in pedagogical and classroom contexts (Hodgson-Drysdale, 2013; Lirola, 2010). Most of these studies have aimed mainly to find ways to improve the writing abilities of EFL and ESL students; however, their research contexts were generally outside Japan. Chen and Su (2012), for example, determined that the SFL genre approach in their 10-week summary writing class was effective for EFL students in Taiwan in developing content and rhetorical organization. However, one of the research limitations of their study was the number of participant groups and the research instrument, pre- and post-tests. Recently, the genre-based approach of the SFL framework has been increasingly focused on writing research in the classroom context in Japan (Mizusawa, 2010; Hisaoka, 2012; Watanabe, 2016; Yasuda, 2011; Fujioka, 2016).

Mizusawa (2010) applied SFL to analyze lexicogrammatical resources as influenced by a writer's evaluation of academic essays written by non-Japanese students who studied in Japan. The following concepts were applied in that study: the research framework and the process of assessing the students' understanding of the language features of the target genre texts. These concepts were also applicable in the current study, despite the relatively low number of participants.

Watanabe (2016) investigated the micro-genres of writing composition tasks for university entrance examinations in Japan, focusing on the analysis of the common generic structures used by most students in Japan. The results showed that a narrow range of genre types of written texts, such as exposition genre text and personal reflections, were required in entrance examinations taken by high school students who had learned English (Watanabe, 2016). For instance, personal reflection was a common type of writing taught to students in the early stages of primary school in Australia (Martin \& Rohery, 1980; Watanabe, 2016). Watanabe (2016) concluded that the limited range of generic structures and genre types in entrance examinations may motivate students who write effectively only within this limited range of genre texts.

Hisaoka (2012) argued that analytic rating and objective language measurements are the two primary methods of assessing writing and composition in Japan. These assessments focus on, first, vocabulary, usage, and mechanics for evaluating how well writers write; and second, content and organization for determining what they mean. These assessment criteria are separated between lexicogrammatical features and language and meaning. Hisaoka (2012) suggested that the concept of SFL can be applied to both aspects. An alternative assessment criterion based on the concept of SFL is introduced in the current research.

Fujioka (2016) focused on an English academic writing course for graduate students working in science fields that used a genre-based approach; a similar teaching methodology using the genre-based approach was applied in the current study. Finally, 70 Japanese undergraduates who were novice writers participated in writing tasks using the SFL genre approach with a task-based pedagogy in Yasuda (2011). That study confirmed that this approach enabled the students to improve their genre awareness and command of lexicogrammatical features.

In conclusion, the aforementioned studies have focused on the following specific elements: the classroom 
context in Japan; the genre-based approach to writing; Japanese EFL students; the appropriate means of assessing generic structures and language features; the development of metacognitive skills; and genre awareness. One of challenges of the current study was to combine these various aspects in order to evaluate learners' development in terms of their genre awareness and writing proficiency, in the context of a genre-based, SFL-oriented approach.

\section{Method}

\subsection{Research Questions}

RQ1: How does the genre awareness of first-year Japanese students change over one semester in a general EAP writing class? RQ2: What features (generic structures and lexicogrammatical choices) of the target genre were the EFL students most aware of after the 15 -week course?

\subsection{Participants}

Fourteen first-year university students (eight females and six males), whose command of English was graded at the intermediate proficiency level (B1) according to the Common European Framework of Reference for Language (CEFR) in Japan, participated in the study, which encompassed a 15-week course during the 2017 academic year. All of the participants were independent students who understood the details of familiar topics such as school, leisure, and personal interest; however, all of them had difficulty using the target language flexibly and effectively for academic and professional purposes. Their social practice during the course was intended to improve their English proficiency sufficiently to allow them to participate in a year-long study abroad project, which is required for graduation; they were also expected to improve their fluency enough to write argumentative essays and to understand international students from different cultural backgrounds. In order to assess their L2 writing experience before they entered university, the 14 students completed a survey at an early stage of the course. All of the study participants provided informed consent before the 15 -week course was begun. The survey items were based on Browne and Wada (1998). The results revealed that the students' previous literacy activities in high school that addressed such genre-based writing experience, analyzing peer's essays, and reading were limited (Table 1). Thus, they were considered novices in genre-based writing.

Table 1. The 14 students' writing experience in Japanese high schools

\begin{tabular}{ll}
\hline Writing experiences in classroom & $n$ \\
\hline Translation drills (Japanese to English and vice versa) & 9 \\
Writing essays including an introduction, body, and conclusion & 6 \\
Writing one or two sentences in English & 5 \\
Using different genre texts through the genre-based approach to writing & 5 \\
Paragraph writing practice, including topic sentences and support evidence & 3 \\
Analyzing peers' essays & 1 \\
\hline
\end{tabular}

Note. One student did not respond to these items due to being absent on the day of the survey.

\subsection{The SFL-Oriented, Genre-Based Pedagogical Approach to Writing Employed in This Study}

One of the demands faced by university students is the requirement to write effectively in Japanese and English, in order to complete academic reports and similar assignments (Yoshihara, 2004). Some EFL students have difficulty identifying the vocabulary and grammar appropriate for a particular purpose, and may have trouble writing essays that meet the objectives of a specific genre. Consequently, approaches to the teaching of writing have undergone a shift to include genre theory and the notion of writing for specific purposes, evolving beyond traditional grammar-translation methods (Belcher, 2004). McKinley (2010) asserts that the model-product approach, which focuses similarly on writing for specific purposes and the concept of genre, has become more common in Japan.

A 15-week sequence of genre-based EFL instruction for undergraduates majoring in international studies at an unnamed Japanese university was conducted, by the present author, based on approaches to lesson planning developed by Knapp and Watkins (2005), Rose (2012), Chen and Su (2012), the University of New South Wales (UNSW) Department of School Education (1989), Abbaszadeh (2013), and Troyan (2013). Halliday's (1994) SFL teaching framework was also influential in respect of the current study, as were the pedagogical 
implications of Martin's $(2001,2009)$ genre approach to language learning, and the text-based language pedagogy and curricula of Mickan (2013) and Mickan and Lopez (2017). Thus, the students who participated in the current study were enabled to understand the generic structure and lexicogrammatical aspects of the target texts and why writers are required to use appropriate vocabulary and structure in order to create meaning.

The idea underlying a genre-based approach to writing is that texts differ in their purposes, and that meanings can be communicated through language in different ways depending on the discourses that prevail in different cultures (Lingzhu, 2009). In this study, students learned to critically analyze written texts and develop the ability to think logically through a genre-based approach to language learning based on Feez's (2002) teaching and learning cycle (Figure 2). In this approach, students acquire the skills necessary to present their thoughts in different written styles by practicing the production of a variety of genres in the context of individual and group writing activities.

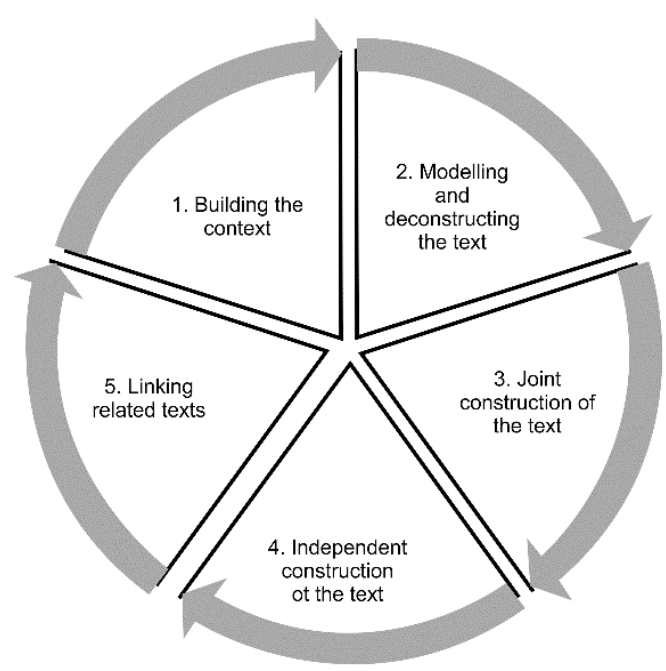

Figure 2. The teaching and learning cycle

Note. Referred from Feez (2002, p. 65) and Hyland (2007 p. 159).

The 15-week course applied a set of learning steps derived from Feez's (2002) teaching and learning cycle. One of the target genres was the discussion essay. The steps of the teaching and learning cycle comprised: 1) building a context; 2) modeling and deconstructing an existing text; and 3) independently constructing a new text. In the second and third steps, the teacher explained the target genre's purpose, and its structure and language features. In the fourth step, students completed a 50- to 60-minute timed writing exercise. After this, we returned to the second step, further deconstructing the text. At this point, three tasks were assigned in order to assess students' understanding. In Task 1, the students analyzed essays written by their peers, in relation to the structure and language features of the target genre. The questions that comprised this peer genre analysis task, which are listed in Table 2, were especially focused on modal verbs and the features of the generic structures. The task involved students reflecting on their peers' writing in order to increase their own genre awareness (Yasuda, 2011; Nagao, 2017). In Task 2, the students shared and discussed their genre analyses with one another, as a group activity, trying to discern similarities and differences. In Task 3, students were prompted to reflect on their learning in relation to genre writing and analysis. Table 3 presents a summary of the 15 -week course. 
Table 2. Questions for the peer genre essay analysis task (based on Yasuda, 2011; Nagao, 2017)

\begin{tabular}{l}
\hline 1. Generic structures \\
\hline In the first paragraph, how was the topic introduced and developed? \\
In the final paragraph, where did the author present his or her opinion? \\
\hline 2. Language features \\
What verbal verbs (reporting verbs) were used in this essay (experiential meaning)? \\
What types of lexicogrammatical features were used to express the writer's opinion (interpersonal \\
meaning)? Analyze the language features (modalities and modal verbs such as will, can, should, and need \\
to) in each paragraph. \\
What types of lexicogrammatical features were used to introduce different opinions in this essay (signposts \\
such as "on the other hand" and "as for the opponent's opinion," which build textual meaning)?
\end{tabular}

Table 3. Summary of the 15-week course

\begin{tabular}{|c|c|c|c|}
\hline Week & Themes & Contents & Data \\
\hline 1 & Orientation & Setting the context and establishing the field & \\
\hline 2 & & $\begin{array}{l}\text { Pre-discussion timed genre essay task (without detailed } \\
\text { instruction about the genre or about the peer analysis task) }\end{array}$ & $\begin{array}{l}\text { Pre-essay } \\
\text { *Pre-survey }\end{array}$ \\
\hline 3 & & $\begin{array}{l}\text { Modeling and deconstruction; } \\
\text { independent construction of essay }\end{array}$ & Essay \\
\hline 4 & $\begin{array}{l}\text { Recount genre } \\
\text { text }\end{array}$ & $\begin{array}{l}\text { Independent construction (revision) } \\
\text { Tasks } 1 \text { and } 2\end{array}$ & \\
\hline 5 & & $\begin{array}{l}\text { Task } 3 \\
\text { Linking to related texts }\end{array}$ & $\begin{array}{l}\text { Self-reflection on peer } \\
\text { essay analysis }\end{array}$ \\
\hline 6 & $\begin{array}{l}\text { Using the } \\
\text { textbook }\end{array}$ & & \\
\hline 7 & \multirow{4}{*}{$\begin{array}{l}\text { Descriptive } \\
\text { genre essay }\end{array}$} & Setting the context and establishing the field & \\
\hline 8 & & Modeling and deconstruction; independent construction & Essay \\
\hline 9 & & $\begin{array}{l}\text { Independent construction (revision) } \\
\text { Tasks } 1 \text { and } 2\end{array}$ & \\
\hline 10 & & $\begin{array}{l}\text { Task } 3 \\
\text { Linking to related texts }\end{array}$ & $\begin{array}{l}\text { Self-reflection on own } \\
\text { peer essay analysis }\end{array}$ \\
\hline 11 & $\begin{array}{l}\text { Using the } \\
\text { textbook }\end{array}$ & & \\
\hline 12 & \multirow{4}{*}{$\begin{array}{l}\text { Discussion } \\
\text { genre essay }\end{array}$} & Setting the context and establishing the field & \\
\hline 13 & & $\begin{array}{l}\text { Modeling and deconstruction; independent construction of } \\
\text { essay }\end{array}$ & Post-essay \\
\hline 14 & & $\begin{array}{l}\text { Independent construction (revision) } \\
\text { Tasks } 1 \text { and } 2\end{array}$ & *Post-survey \\
\hline 15 & & $\begin{array}{l}\text { Task } 3 \\
\text { Linking to related texts }\end{array}$ & $\begin{array}{l}\text { *Self-reflection on peer } \\
\text { essay analysis }\end{array}$ \\
\hline
\end{tabular}

Note. ${ }^{*}$ These data were derived from analyses undertaken for this research.

\subsection{Data Sources}

3.4.1 Non-Instructional and Instructional Writing Tasks

Discussion genre essays (argumentative essays) were collected from the students at the beginning of the first 
semester as a non-instructional writing task and again at end of the semester as an instructional writing task, using the genre-based approach with a teaching and learning cycle (Figure 2). Both the non-instructional and instructional writing sessions were conducted during regular class time. The students then participated in timed writing tasks of 60 minutes (creating either discussion or argumentative essays) on the following topics: 1) "University students nowadays have too much freedom and do not study enough." Explain both opinions on this statement and finally write your opinion, using specific reasons and examples" (non-instructional writing task). 2) "Would affirmative action help women in Japan?" (instructional writing task).

\subsubsection{Analysis Sheet (Self-Reflection Analysis Written Texts on the Results of the Peer Genre Analysis Task)}

To elicit in-depth qualitative insights into how to improve students' awareness and perceptions of generic structure and language features, 11 participants were asked to write self-reflection essays on their experience in the peer genre analysis study. Three students did not participate in this task due to being absent. Following the elaborate instructional writing task conducted at the end of the semester, when the students completed the genre essay analysis task on peer essays (Table 1), they were also asked to reflect on their results of the task, which was conducted in Japanese and took up approximately one-third of the 90-minute class period. The students compared their essays with their partner's and discussed the different features of each one. For instance, regarding the modal verbs (the lexicogrammatical feature of the discussion essay), one student responded:

"In my essay, I wrote the modal verb "can" five times in the final paragraph. On the other hand, my partner: Student 13 used the same modal verb "can" once in the first paragraph and three times in the last paragraph. I used the word in the last paragraph only because the writer [was asked to] express his or her feelings in the last paragraph. I do not [know] why Student 13 used it in the first paragraph (extracted from student 13's self-reflection analysis sheet.)".

The open-ended reflection prompts were as follows: 1) "Please compare the different features of 'interpersonal meaning,' 'textual meaning,' and 'experiential meaning' in your essay and your partner's essay." 2) "Please write freely about some new things you learned when engaging in a genre analysis of a peer's discussion essay." 3 ) "What was the most difficult feature to analyze in a peer's essay?" (Yasuda, 2015).

\subsubsection{Pre- and Post-surveys}

To gain in-depth qualitative insights into how the students' genre awareness and grasp of the uses of lexicogrammar in the target genre changed, pre- and post-instructional surveys were administered. Table 4 lists the survey questions, which were adapted from Deng, Yang and Varaprasad (2014). The participants were asked to rate each statement on a 5-point Likert scale, to indicate the extent to which they agreed or disagreed with it; 5 indicated strongly agree and 1 indicated strongly disagree. At the time that the pre-survey was administered, students had had practice in non-instructional discussion essay writing but not in genre essay analysis of peer essays. On the other hand, when the post-survey was administered, the students had practiced limited instructional writing and had sufficient time to analyze their peers' essays according to the Feez (2002) teaching and learning cycle (Table 3).

Table 4. Pre- and post-survey questions

\begin{tabular}{ll}
\hline No. & Items (Questions) \\
\hline 1 & I understood the discussion essay in general. \\
2 & I completely understood how to write the introduction section of the discussion essay. \\
3 & I completely understood how to write Paragraphs 2 and 3 of the final essay. \\
4 & I completely understood how to write the conclusion section of the final essay. \\
5 & $\begin{array}{l}\text { I completely understood the elements (nuance regulation, textual meaning, interpersonal meaning, and } \\
\text { experiential meaning) required in the introduction section of the final essay. }\end{array}$ \\
6 & $\begin{array}{l}\text { I completely understood the elements (nuance regulation, textual meaning, interpersonal meaning, and } \\
\text { experiential meaning) required in the body of the final essay. }\end{array}$ \\
7 & $\begin{array}{l}\text { I completely understood the elements (nuance regulation, textual meaning, interpersonal meaning, and } \\
\text { experiential meaning) required in the conclusion section of the final essay. }\end{array}$ \\
9 & $\begin{array}{l}\text { Regarding the final essay, I was particularly good at writing that type of essay. } \\
10\end{array}$ \\
\hline
\end{tabular}


11 I was particularly good at writing the conclusion section of the final essay.

12 I was particularly good at writing the reference section of the final essay.

13 I now understand that discussion genre essays are for the mentoring skills of teaching.

14 My ability to write discussion genre essays was improved through peer interactions and peer analysis.

15 I think that taking this course helped develop my writing ability.

16 I think that reading research articles helped improve my writing ability.

17 I think that reading books improved my writing ability.

18 I think that writing essays similar to the final essay increased my writing ability.

Note. Questions were referred from Deng, Yang and Varaprasad (2014).

\subsection{Data Coding and Analysis}

The analysis sheet (self-reflection written texts) were collected at the end of each semester, and the discussion essays and the survey data were collected at the beginning and end of the semester (Table 5). In this study, the self-reflection data related to participation in the peer discussion essay analysis and the pre- and post- survey data were examined.

Table 5. Data collection dates

\begin{tabular}{lll}
\hline Sources & Pre & Post \\
\hline Discussion essays & April 13, 2017 & July 5, 2017 \\
Analysis sheet (self-reflection written texts) & $/$ & July 13, 2017 \\
Surveys & April 17, 2017 & July 20, 2017 \\
\hline
\end{tabular}

To understand the students' genre awareness, their self-reflection written texts were analyzed using 12 criteria adapted form Burns, Joyce, and Gollin (1996), to assess how they used generic structure and lexicogrammar related to discussion essays (Table 6). The target genre in this study was the discussion text (argumentative essay), composed using the generic structure and language features listed in Table 6. This table and an accompanying explanation were used to introduce the following tasks to the students: modeling and deconstructing the text, independently constructing the text, conducting a genre analysis of a peer's essay, and, finally, writing a self-reflection essay.

Table 6. Assessment criteria adapted from Burns, Joyce, and Gollin (1996 p. 94)

\begin{tabular}{|c|c|c|}
\hline Groups & Categories & Criteria \\
\hline \multirow{2}{*}{$\begin{array}{l}1 \\
\text { Generic } \\
\text { Structure }\end{array}$} & $\begin{array}{l}\text { Identifies sociocultural } \\
\text { purpose of genre }\end{array}$ & (1) To identify the purpose of the discussion essay \\
\hline & $\begin{array}{l}\text { Identifies motivation } \\
\text { of genre as } \\
\text { interpersonal or } \\
\text { pragmatic }\end{array}$ & $\begin{array}{l}\text { (2) To describe the structure of the target genre: 1) issue; 2) } \\
\text { argument for; 3) argument against; 4) conclusion }\end{array}$ \\
\hline \multirow{7}{*}{$\begin{array}{l}2 \\
\text { Lexicogrammar }\end{array}$} & \multirow{4}{*}{$\begin{array}{l}\text { Ideational meaning: } \\
\text { Field }\end{array}$} & (3) To explain general personal nouns \\
\hline & & (4) To write about uses of abstract nouns \\
\hline & & (5) To write about uses of action verbs \\
\hline & & (6) To write about uses of "verbal verbs" \\
\hline & \multirow{3}{*}{$\begin{array}{l}\text { Interpersonal meaning: } \\
\text { Tenor }\end{array}$} & (7) To write about modalities; e.g., will, can, should, and need to \\
\hline & & $\begin{array}{l}\text { (8) To write about modality }+ \text { adverbs such as typically, } \\
\text { absolutely, and definitely }\end{array}$ \\
\hline & & $\begin{array}{l}\text { (9) To write these fixed phrases to express the writer's } \\
\text { opinion/modality: It is possible that, I guess that, and It is certain }\end{array}$ \\
\hline
\end{tabular}




\begin{tabular}{|c|c|}
\hline & that \\
\hline \multirow{3}{*}{$\begin{array}{l}\text { Textual meaning: } \\
\text { Mode }\end{array}$} & (10) To explain construct conjunctions \\
\hline & (11) To explain demonstrative pronouns such as that and this \\
\hline & $\begin{array}{l}\text { (12) To use appropriate thematic ties and referential links to } \\
\text { extend genre }\end{array}$ \\
\hline
\end{tabular}

In Phase 2, RQ2 was explored to determine the generic structures and lexicogrammatical choices of the target genre that the EFL students were most aware of. The same data (on the analysis sheet related to the self-reflection written texts) were collected at the end of the semester and analyzed using frequency analysis.

\section{Results}

\subsection{Phase 1: Pre- and Post-Surveys}

RQ1: How does the genre awareness of Japanese first-year students change over one semester in the general EAP writing class? To investigate how the students conceptualized the discussion essay and its language features at the beginning of the semester, their responses to the 18 survey questions were quantitatively and qualitatively analyzed (Table 7). The numbers reported in the table represent the numbers of students whose answer included a particular idea unit.

Table 7 lists the descriptive statistics of the results of the survey that the students answered immediately after describing the discussion essay. For the pre-data, a non-instructional timed writing task was conducted; for the post-data, the students filled out a survey immediately after participating in the instructional timed writing task. Table 8 presents the reliability coefficients. First, Cronbach's awas shown to be high enough for later analysis. For 1) Understanding of the generic structure, the Cronbach's $\alpha$ was .92 for the pre-data and .87 for the post-data; for 2) Understanding of the linguistic features, the Cronbach's $\alpha$ was .99 for the pre-data and .92 for the post-data; for 3) Awareness of being good, the Cronbach's $\alpha$ was .89 for the pre-data and .85 for the post-data; and for 4) Factors that improved abilities, the Cronbach's $\alpha$ was .81 for the pre-data and .71 for the post-data. Thus, a high level of consistency was obtained. These results suggest the need for caution when interpreting the results for 4) Factors that improved abilities. When the Kolmogorov-Smirnov and Shapiro-Wilk $p$-values are .05 or higher, the data have a normal distribution. However, the results of the data analysis indicate that these data did not have a normal distribution. Therefore, the $p$-values were analyzed using a Wilcoxon signed rank sum test, which revealed three groups with significant differences: 1) Understanding of the generic structure, 2) Understanding of the linguistic features/lexicogrammar, and 3) Awareness of confidence regarding how to write the target genre essay. Significant differences between the results of the pre- and post-data were determined in item 3 ("I completely understood how to write Paragraphs 2 and 3 of the final essay"), item 6 ("I completely understood the elements [nuance regulation, textual meaning, interpersonal meaning, and experiential meaning[ required in the body of the final essay"), and item 10 ("I was particularly good at writing the body section of the final essay"). These results demonstrate that the students understood how to compose the second and third paragraphs in a discussion essay and what lexicogrammar is in relation to appropriate textual meaning, interpersonal meaning, and experiential meaning. Moreover, comparing the pre- and post-data analyses indicated that the students' abilities to understand the composition and linguistic features of the target genre and their awareness of writing competent descriptions in second and third paragraphs had improved.

When the pre- and post-survey data were compared, the mean average declined for the following items. Data collated under the third category (Group 3, Awareness of Possessing Strong Writing Abilities), for example, showed that the mean average increased for the following items: "Regarding the final essay, I was particularly good at writing that type of essay (I8)," and "I was particularly good at writing the introduction section of the final essay (I9)." Furthermore, the mean average for the following three items under Group 4 (Factors that Improved Abilities) increased: "I think that reading research articles helped enhance my writing ability" (I16), "I think that reading books improved my writing ability" (I17), and "I think that writing essays similar to the final essay honed my writing ability" (I18). Based on our analysis of these results, we found that students who underwent genre-based approach language training and took part in instructed timed writing tasks as part of a teaching and learning cycle immediately prior to participating in the post-survey experienced lowered confidence in their ability to write discussion-genre essays, particularly introductions. The analysis also showed that the number of students who believed that reading research papers and books and writing similar essays had improved their ability to write discussion essays had decreased. 
Table 7. Pre- and post-survey descriptive statistics

\begin{tabular}{|c|c|c|c|c|c|c|c|}
\hline \multirow[t]{2}{*}{ Groups } & \multirow[t]{2}{*}{ Items } & \multicolumn{2}{|l|}{ Mean } & \multirow[t]{2}{*}{$S D$} & \multicolumn{2}{|c|}{$\begin{array}{l}\text { Kolmogorov-Smirnov } \\
\text { normality test } \\
\text { (exploratory) }\end{array}$} & \multirow[t]{2}{*}{$P$-values } \\
\hline & & Pre-survey & Post-survey & & Pre & Post & \\
\hline \multirow{4}{*}{$\begin{array}{l}\text { (1) Understanding of } \\
\text { the generic structure }\end{array}$} & 1 & 3.00 & 3.79 & 1.109 & 0.200 & 0.002 & 0.078 \\
\hline & 2 & 2.93 & 3.36 & 1.141 & 0.076 & 0.089 & 0.271 \\
\hline & 3 & 2.93 & 3.79 & 0.997 & 0.014 & 0 & $0.016^{*}$ \\
\hline & 4 & 2.86 & 3.29 & 0.949 & 0.124 & 0.09 & 0.250 \\
\hline \multirow{3}{*}{$\begin{array}{l}\text { (2) Understanding of } \\
\text { the linguistic } \\
\text { features/ } \\
\text { lexicogrammar }\end{array}$} & 5 & 2.50 & 3.14 & 0.855 & 0.002 & 0.007 & 0.058 \\
\hline & 6 & 2.50 & 3.29 & 0.855 & 0.002 & 0.013 & $0.026^{*}$ \\
\hline & 7 & 2.57 & 2.86 & 0.938 & 0.02 & 0.002 & 0.405 \\
\hline \multirow{5}{*}{$\begin{array}{l}\text { (3) Awareness of } \\
\text { possessing strong } \\
\text { writing abilities }\end{array}$} & 8 & 2.79 & 2.57 & 1.051 & 0.006 & 0.006 & 0.453 \\
\hline & 9 & 2.64 & 2.64 & 0.745 & 0 & 0.169 & 0.927 \\
\hline & 10 & 2.36 & 3.14 & 0.745 & 0.001 & 0.001 & $0.038^{*}$ \\
\hline & 11 & 2.36 & 2.50 & 0.633 & 0.003 & 0.124 & 0.608 \\
\hline & 12 & 2.21 & 2.86 & 0.699 & 0.009 & 0.032 & 0.141 \\
\hline \multirow{6}{*}{$\begin{array}{l}\text { (4) Factors that } \\
\text { improved abilities }\end{array}$} & 13 & 3.93 & 3.93 & 0.829 & 0 & 0.001 & 0.886 \\
\hline & 14 & 3.71 & 3.71 & 0.825 & 0.004 & 0.004 & 0.963 \\
\hline & 15 & 3.43 & 3.64 & 0.938 & 0.001 & 0 & 0.465 \\
\hline & 16 & 3.00 & 2.64 & 0.784 & 0 & 0.047 & 0.403 \\
\hline & 17 & 3.71 & 2.86 & 0.825 & 0.004 & .200 & 0.053 \\
\hline & 18 & 3.71 & 3.43 & 0.825 & 0.004 & 0.054 & 0.366 \\
\hline
\end{tabular}

Note. $*=p<.05$

Table 8. Cronbach's $\alpha$ for each group

\begin{tabular}{lll}
\hline Cronbach's $\alpha$ & & \\
\hline Groups & Pre-survey & Post-survey \\
(1) Understanding of the generic structure & 0.923 & 0.876 \\
(2) Understanding of the linguistic features/lexicogrammar & 0.990 & 0.926 \\
(3) Awareness of possessing strong writing abilities & 0.893 & 0.858 \\
(4) Factors that improved abilities & 0.816 & 0.716 \\
\hline
\end{tabular}

\subsubsection{Understanding of the Generic Structure (Pre-survey)}

The results of the pre-survey are presented in Table 9. Regarding the students' understanding of an introduction to a previously written essay, within Group 4, a correlation was observed between I13 and I15: It was determined that the students' understanding of how to write the introduction of the discussion essay related to "I think that taking this course helped develop my writing ability" (I15) and "I now understand that discussion genre essays are for the mentoring skills of teaching" (I13) had improved. A correlation between "I completely understood how to write Paragraphs 2 and 3 of the final essay" (I3) and guidance from the teacher (I13) was also observed: In other words, the students' understanding of the composition of second and third paragraphs, which constitute the body of a discussion essay, had improved under the teacher's guidance. However, no correlation was observed between the understanding of I4, which concerns how to write the conclusion of a discussion essay, and factors such as the teachers taking the class, mutual learning with other members, and reading books.

\subsubsection{Understanding Linguistic Features/Lexicogrammar (Pre-survey, Table 9)}

For the discussion essay, understanding of the linguistic features of textual meaning, interpersonal meaning, and experiential meaning was strongly correlated with "an awareness of being good" (skilled) enough to write a 
discussion essay. In addition, an improved understanding of linguistic features was not related to guidance from the teacher (I13), but it was strongly correlated with "My ability to write discussion genre essays was improved through peer interactions and peer analysis [mutual teaching] with other class members" (I14) and "I think that taking this course helped develop my writing ability" (I15). Table 10 presents the results of the analysis on the correlation between each item in the post-survey, in which the data were collected after an instructed-genre writing task.

\subsection{Understanding Structure (Post-Survey)}

For I2, "I completely understood how to write the introduction section of the discussion essay" included in Group 1 (Understanding of the generic structure), correlations were observed not only with all items in Group 2 (Understanding of the linguistic features/lexicogrammar) but also with all those in Group 3 (Awareness of possessing strong writing abilities), except for the statement "I was particularly good at writing the reference section." The reason for the increase in understanding how to write an introduction (I2) was highly correlated with guidance from the teacher (I13) and "I think that taking this course helped develop my writing ability" (I15). An increase in a student's understanding of how to write the second and third paragraphs (I3) was found to be highly correlated with completing the class (I15) and "I think that writing essays similar to the final essay increased my writing ability" (I18).

\subsection{Understanding Linguistic Characteristics (Post-survey Analyses, Table 10)}

There was a correlation between the degree of understanding the linguistic characteristics used for the body of text (I5) and the reasoning that "I completed the class" (I15). Furthermore, the degree of a student's understanding of "Linguistic characteristics used for conclusion" (I6) was correlated with "I think that taking this course helped develop my writing ability" (I15) and "I think that reading books improved my writing ability" (I17), and the degree of understanding linguistic characteristics used for a conclusion (I7) was correlated with reading books (I17).

\subsection{Awareness of Possessing Strong Abilities for Discussion Genre Writing (Post-Survey Analyses, Table 10)}

"I was particularly good at writing that type of essay [discussion]" (I8), "I was particularly good at writing the introduction section" (I9), and "I was particularly good at writing the body section of the final essay." (I10) were correlated with "I now understand that discussion genre essays are for the mentoring skills of teaching" (I13). "I was particularly good at writing the introduction" (I9), "conclusion" (I11), and "reference section" (I12) were correlated with "I think that reading books improved my writing ability" (I17).

Table 9. Results of the correlation analyses for the pre-survey

\begin{tabular}{|c|c|c|c|c|c|c|c|c|c|c|c|c|c|c|c|c|c|c|c|}
\hline & & (1) & & & & (2) & & & (3) & & & & & (4) & & & & & \\
\hline & Items & 1 & 2 & 3 & 4 & 5 & 6 & 7 & 8 & 9 & 10 & 11 & 12 & 13 & 14 & 15 & 16 & 17 & 18 \\
\hline (1) & 1 & 1 & & & & & & & & & & & & & & & & & \\
\hline & 2 & $.547^{*}$ & 1 & & & & & & & & & & & & & & & & \\
\hline & 3 & $.547^{*}$ & $.942^{* *}$ & 1 & & & & & & & & & & & & & & & \\
\hline & 4 & $.657^{*}$ & $.913^{* *}$ & $.963^{* *}$ & 1 & & & & & & & & & & & & & & \\
\hline (2) & 5 & $.657^{*}$ & $.749^{* *}$ & $.767^{* *}$ & $.758^{* *}$ & 1 & & & & & & & & & & & & & \\
\hline & 6 & $.649^{*}$ & $.749^{* *}$ & $.767^{* *}$ & $.758^{* *}$ & $1.000^{* *}$ & 1 & & & & & & & & & & & & \\
\hline & 7 & $.666^{*}$ & $.760^{* *}$ & $.705^{* *}$ & $.704^{* *}$ & $.960^{* *}$ & $.960^{* *}$ & 1 & & & & & & & & & & & \\
\hline (3) & 8 & $.660^{*}$ & 0.435 & 0.498 & 0.507 & $.557^{*}$ & $.557^{*}$ & $.602^{*}$ & 1 & & & & & & & & & & \\
\hline & 9 & $.652^{*}$ & $.782^{* *}$ & $.791^{* *}$ & $.793^{* *}$ & $.664^{* *}$ & $.664^{* *}$ & $.645^{*}$ & $.583^{*}$ & 1 & & & & & & & & & \\
\hline & 10 & 0.465 & $.847^{* *}$ & $.762^{* *}$ & $.730^{* *}$ & $.785^{* *}$ & $.785^{* *}$ & $.787^{* *}$ & 0.400 & $.802^{* *}$ & 1 & & & & & & & & \\
\hline & 11 & 0.438 & $.677^{* *}$ & $.774^{* *}$ & $.731^{* *}$ & $.781^{* *}$ & $.781^{* *}$ & $.666^{* *}$ & 0.471 & $.780^{* *}$ & $.850^{* *}$ & 1 & & & & & & & \\
\hline & 12 & $.892^{* *}$ & $.695^{* *}$ & $.685^{* *}$ & $.745^{* *}$ & $.836^{* *}$ & $.836^{* *}$ & $.855^{* *}$ & $.695^{* *}$ & $.749^{* *}$ & $.728^{* *}$ & $.682^{* *}$ & 1 & & & & & & \\
\hline (4) & 13 & 0.418 & $.564^{*}$ & $.552^{*}$ & 0.475 & 0.489 & 0.489 & $.552^{*}$ & 0.423 & 0.454 & 0.418 & 0.345 & $.559^{*}$ & 1 & & & & & \\
\hline & 14 & 0.084 & 0.467 & 0.347 & 0.238 & $.545^{*}$ & $.545^{*}$ & $.625^{*}$ & 0.456 & 0.447 & $.679^{* *}$ & 0.505 & 0.381 & 0.418 & 1 & & & & \\
\hline
\end{tabular}




$\begin{array}{llllllllllllllllllllll}15 & 0.370 & .678^{* *} & 0.529 & 0.506 & .576^{*} & .576^{*} & .662^{* *} & 0.257 & .566^{*} & .645^{*} & 0.370 & .553^{*} & .735^{* *} & .667^{* *} & 1 & & \\ 16 & 0.088 & 0.430 & 0.393 & 0.310 & 0.459 & 0.459 & 0.418 & 0.280 & 0.527 & .658^{*} & .619^{*} & 0.421 & 0.473 & .713^{* *} & .627^{*} & 1 & & \\ 17 & 0.000 & 0.222 & -0.027 & -0.056 & 0.218 & 0.218 & 0.327 & -0.253 & 0.197 & 0.429 & 0.063 & 0.114 & 0.193 & .548^{*} & .667^{* *} & 0.356 & 1 & \\ 18 & -0.168 & 0.058 & -0.027 & -0.056 & -0.109 & -0.109 & -0.170 & -0.165 & 0.197 & 0.179 & 0.063 & -0.152 & -0.257 & 0.210 & 0.170 & 0.475 & 0.323 & 1\end{array}$

Note. *. $p<.05, * * . p<.01$, (1) Under-standing of the generic structure, (2) Under-standing of the linguistic features/ lexicogrammar, (3) Awareness of possessing strong writing abilities, and (4) Factors that improved writing abilities

Table 10. Results of correlation analyses for the post-survey

\begin{tabular}{|c|c|c|c|c|c|c|c|c|c|c|c|c|c|c|c|c|c|c|c|}
\hline & & (1) & & & & (2) & & & (3) & & & & & (4) & & & & & \\
\hline & Items & 1 & 2 & 3 & 4 & 5 & 6 & 7 & 8 & 9 & 10 & 11 & 12 & 13 & 14 & 15 & 16 & 17 & 18 \\
\hline \multirow{5}{*}{ (1) } & 1 & 1 & & & & & & & & & & & & & & & & & \\
\hline & 2 & $.704^{* *}$ & 1 & & & & & & & & & & & & & & & & \\
\hline & 3 & $.665^{* *}$ & $.772^{* *}$ & 1 & & & & & & & & & & & & & & & \\
\hline & 4 & 0.469 & $.773^{* *}$ & $.585^{*}$ & 1 & & & & & & & & & & & & & & \\
\hline & 5 & 0.529 & $.669^{* *}$ & 0.474 & 0.527 & 1 & & & & & & & & & & & & & \\
\hline \multirow[t]{3}{*}{ (2) } & 6 & 0.505 & $.576^{*}$ & 0.316 & $.580^{*}$ & $.785^{* *}$ & 1 & & & & & & & & & & & & \\
\hline & 7 & 0.387 & $.597^{*}$ & 0.454 & $.640^{*}$ & $.804^{* *}$ & $.856^{* *}$ & 1 & & & & & & & & & & & \\
\hline & 8 & 0.518 & $.622^{*}$ & 0.375 & 0.442 & 0.334 & $.548^{*}$ & 0.338 & 1 & & & & & & & & & & \\
\hline \multirow{4}{*}{ (3) } & 9 & 0.340 & $.721^{* *}$ & $.683^{* *}$ & $.555^{*}$ & 0.452 & 0.510 & $.647^{*}$ & $.655^{*}$ & 1 & & & & & & & & & \\
\hline & 10 & $.601^{*}$ & $.735^{* *}$ & $.581^{*}$ & 0.445 & $.563^{*}$ & 0.484 & 0.458 & $.746^{* *}$ & $.687^{* *}$ & 1 & & & & & & & & \\
\hline & 11 & 0.350 & $.604^{*}$ & 0.409 & $.626^{*}$ & 0.398 & $.740^{* *}$ & $.662^{* *}$ & $.676^{* *}$ & $.736^{* *}$ & $.637^{*}$ & 1 & & & & & & & \\
\hline & 12 & 0.356 & 0.530 & $.535^{*}$ & 0.472 & $.570^{*}$ & 0.491 & $.574^{*}$ & 0.269 & $.548^{*}$ & 0.349 & 0.424 & 1 & & & & & & \\
\hline \multirow[t]{6}{*}{ (4) } & 13 & 0.412 & $.645^{*}$ & 0.460 & $.625^{*}$ & 0.278 & 0.463 & 0.505 & $.590^{*}$ & $.637^{*}$ & $.657^{*}$ & $.797^{* *}$ & 0.488 & 1 & & & & & \\
\hline & 14 & 0.013 & -0.046 & -0.247 & 0.015 & -0.039 & 0.295 & 0.046 & 0.452 & 0.042 & 0.052 & 0.396 & 0.237 & 0.250 & 1 & & & & \\
\hline & 15 & $.782^{* *}$ & $.560^{*}$ & $.702^{* *}$ & 0.492 & $.541^{*}$ & $.535^{*}$ & 0.506 & 0.369 & 0.468 & $.622^{*}$ & 0.484 & 0.508 & 0.517 & 0.143 & 1 & & & \\
\hline & 16 & -0.072 & 0.172 & -0.109 & 0.189 & 0.465 & 0.460 & 0.517 & 0.121 & 0.290 & 0.188 & 0.416 & 0.331 & 0.136 & 0.480 & 0.060 & 1 & & \\
\hline & 17 & 0.212 & 0.473 & 0.498 & 0.449 & 0.504 & $.601^{*}$ & $.702^{* *}$ & 0.295 & $.747^{* *}$ & 0.504 & $.731^{* *}$ & $.727^{* *}$ & $.625^{*}$ & 0.032 & $.625^{*}$ & 0.363 & 1 & \\
\hline & 18 & 0.422 & 0.298 & $.534^{*}$ & 0.254 & 0.079 & 0.233 & 0.152 & 0.426 & 0.505 & 0.216 & 0.375 & 0.358 & 0.277 & 0.232 & $.543^{*}$ & 0.009 & 0.393 & 1 \\
\hline
\end{tabular}

Note. ${ }^{*} . p<.05,{ }^{* *} . p<.01,(1)$ Under-standing of the generic structure, (2) Under-standing of the linguistic features/ lexicogrammar, (3) Awareness of possessing strong writing abilities, and (4) Factors that improved writing abilities

\subsection{Phase 2: Generic Structure and Language Features: Results of 12-Criteria Assessment}

RQ2: What features (generic structures and lexicogrammatical choices) of the target genre were EFL students most aware of? To investigate RQ2, analysis sheets ("Self-Reflection Analysis of Written Texts on the Results of the Peer Genre Analysis Task") were analyzed using the 12 criteria adapted from Burns, Joyce, and Gollin (1996, p. 94). Tables 11 and 12 present information on the students' awareness, assessed through their genre analysis of their peers' essays. The resulting data clearly indicate that the students had improved understanding of the structure of this target genre. Twenty-nine percent $(n=10)$ of the students explained their understanding of how to describe the structure of the target genre as follows: 1) issue, 2) argument for, 3) argument against, and 4) conclusion. Twenty-six percent $(n=9)$ of the students were able to identify the purpose of a discussion essay, although they had more difficulty exhibiting their awareness of lexicogrammar. Some of the students wrote about their understanding of what constituted an appropriate choice of tenor. Their understanding of interpersonal meaning was also revealed in the results: 15 percent $(n=5)$ described the uses of modalities such as will, can, should, and need to; 9 percent $(\mathrm{n}=3)$ explained their understanding of how writers use modal 
adverbs (typically, absolutely, definitely) to control the degree of a claim (argument). One of the characteristics of the students' understanding of lexicogrammar was the relationship between explaining the use of constructive conjunctions and generic structure in order to clarify which features (e.g., the generic structure and lexicogrammatical choices of a target genre) were the most significant to each student. The results indicate that reflecting textual meaning is challenging for these students.

Figure 3 illustrates each student's result regarding their awareness of generic structure and language using the 12-criteria assessment. As shown in Figure 3, only Student 8 elaborated on her understanding of writing constructive conjunctions in her essay. For instance, in this target genre, the author introduces the topic in the first paragraph and presents the arguments for and against the topic, along with supporting evidence for each one, in the second and third paragraphs; finally, the author provides his or her own recommendation and opinion in the fourth paragraph. Student 8 wrote in her self-reflection analysis about the uses of construct conjunctions:

In my discussion essay, I thought this strategy for the generic structure was better. For example, if the author wanted to present an opposing opinion in the fourth paragraph, the supporting opinion for the topic should be explained first in the second paragraph, and then the arguments from the opponent side should be explained in the third paragraph. I would like to use constructive conjunctions such as "however" and "but" at the beginning of the third paragraph because such words are useful in emphasizing the content of the third paragraph (the opposing opinion).

In addition, most of the students had difficulty explaining the use of appropriate thematic ties and referential links to other genres. Although these features revealed certain limitations of this research, these outcomes can provide indications of better ways for EFL teachers to help their students improve their language skills.

Table 11. Generic structure and language features: results of 12-criteria assessment (part 1)

\begin{tabular}{|c|c|c|c|c|c|c|c|c|c|c|}
\hline \multirow[t]{2}{*}{ Groups } & \multirow[t]{2}{*}{ Categories } & \multirow[t]{2}{*}{ Criteria } & \multicolumn{8}{|c|}{ Students } \\
\hline & & & S1 & $\mathrm{S} 2$ & S3 & S4 & S5 & S6 & S7 & S8 \\
\hline \multirow{2}{*}{$\begin{array}{l}1 \\
\text { Generic } \\
\text { Structure }\end{array}$} & & $\begin{array}{l}\text { 1. To identify the purpose of the discussion } \\
\text { genre essay }\end{array}$ & 1 & 0 & 0 & 1 & 1 & 0 & 0 & 1 \\
\hline & & $\begin{array}{l}\text { 2. To be able to describe the structure of the } \\
\text { target genre: } 1 \text {. issue, } 2 \text {. argument for, } 3 \text {. } \\
\text { argument against, and } 4 \text {. conclusion }\end{array}$ & 1 & 0 & 0 & 1 & 1 & 0 & 0 & 1 \\
\hline \multirow{10}{*}{$\begin{array}{l}2 \\
\text { Lexico- } \\
\text { grammar }\end{array}$} & \multirow{4}{*}{$\begin{array}{l}\text { Ideational } \\
\text { Meaning: } \\
\text { Field }\end{array}$} & 3. To explain general personal nouns & 1 & 0 & 0 & 1 & 1 & 0 & 0 & 0 \\
\hline & & 4. To write about uses of abstract nouns & 0 & 0 & 0 & 0 & 1 & 0 & 0 & 0 \\
\hline & & 5. To write about uses of action verbs & 0 & 0 & 0 & 0 & 0 & 0 & 0 & 0 \\
\hline & & 6. To write about uses of "verbal verbs" & 0 & 0 & 0 & 0 & 0 & 0 & 0 & 0 \\
\hline & \multirow{3}{*}{$\begin{array}{l}\text { Interpersonal } \\
\text { meaning: } \\
\text { Tenor }\end{array}$} & $\begin{array}{l}\text { 7. To write about modalities: will, can, } \\
\text { should, and need to }\end{array}$ & 0 & 0 & 0 & 0 & 0 & 1 & 0 & 1 \\
\hline & & $\begin{array}{l}\text { 8. To write about modality }+ \text { adverbs such } \\
\text { as typically, absolutely, and definitely }\end{array}$ & 1 & 0 & 0 & 1 & 0 & 0 & 0 & 0 \\
\hline & & $\begin{array}{l}\text { 9. To write these fixed phrases in order to } \\
\text { express the writer's opinion/modality: It is } \\
\text { possible that, I guess that, and It is certain } \\
\text { that }\end{array}$ & 0 & 0 & 0 & 0 & 0 & 0 & 0 & 0 \\
\hline & \multirow{3}{*}{$\begin{array}{l}\text { Textual } \\
\text { meaning: } \\
\text { Mode }\end{array}$} & 10. To explain construct conjunctions & 0 & 0 & 0 & 0 & 0 & 0 & 0 & 1 \\
\hline & & $\begin{array}{l}\text { 11. To explain demonstrative pronouns such } \\
\text { as that and this }\end{array}$ & 0 & 0 & 0 & 0 & 0 & 0 & 0 & 0 \\
\hline & & $\begin{array}{l}\text { 12. To use appropriate thematic ties and } \\
\text { referential links to extend genre }\end{array}$ & 0 & 0 & 0 & 0 & 0 & 0 & 0 & 0 \\
\hline
\end{tabular}


Table 12. Generic structure and language features: results of 12-criteria assessment (part 2)

\begin{tabular}{|c|c|c|c|c|c|c|c|c|c|}
\hline \multirow[t]{2}{*}{ Groups } & \multirow[t]{2}{*}{ Categories } & \multirow[t]{2}{*}{ Criteria } & \multicolumn{7}{|c|}{ Students } \\
\hline & & & S9 & S10 & S11 & S12 & S13 & S14 & $n$ \\
\hline \multirow{2}{*}{$\begin{array}{l}1 \\
\text { Generic } \\
\text { Structure }\end{array}$} & & $\begin{array}{l}\text { 1. To identify the purpose of the } \\
\text { discussion genre essay }\end{array}$ & 1 & 1 & 0 & 1 & 1 & 1 & 9 \\
\hline & & $\begin{array}{l}\text { 2. To be able to describe the structure } \\
\text { of the target genre: } 1 \text {. issue, } 2 \text {. } \\
\text { argument for, } 3 \text {. argument against, } \\
\text { and } 4 \text {. conclusion }\end{array}$ & 1 & 1 & 1 & 1 & 1 & 1 & 10 \\
\hline 2 & & 3. To explain general personal nouns & 0 & 0 & 0 & 1 & 0 & 0 & 4 \\
\hline \multirow[t]{9}{*}{$\begin{array}{l}\text { Lexico- } \\
\text { grammar }\end{array}$} & $\begin{array}{l}\text { Ideational } \\
\text { meaning: }\end{array}$ & $\begin{array}{l}\text { 4. To write about uses of abstract } \\
\text { nouns }\end{array}$ & 1 & 0 & 0 & 0 & 0 & 0 & 2 \\
\hline & Field & 5. To write about uses of action verbs & 0 & 0 & 0 & 0 & 0 & 0 & 0 \\
\hline & & $\begin{array}{l}\text { 6. To write about uses of "verbal } \\
\text { verbs" }\end{array}$ & 0 & 0 & 0 & 0 & 0 & 0 & 0 \\
\hline & \multirow{3}{*}{$\begin{array}{l}\text { Interpersonal } \\
\text { meaning: } \\
\text { Tenor }\end{array}$} & $\begin{array}{l}\text { 7. To write about modalities: will, } \\
\text { can, should, and need to }\end{array}$ & 0 & 0 & 0 & 1 & 1 & 1 & 5 \\
\hline & & $\begin{array}{l}\text { 8. To write about modality }+ \text { adverbs } \\
\text { such as typically, absolutely, and } \\
\text { definitely }\end{array}$ & 0 & 0 & 0 & 0 & 1 & 0 & 3 \\
\hline & & $\begin{array}{l}\text { 9. To write these fixed phrases in } \\
\text { order to express the writer's } \\
\text { opinion/modality: It is possible that, I } \\
\text { guess that, and It is certain that }\end{array}$ & 0 & 0 & 0 & 0 & 0 & 0 & 0 \\
\hline & \multirow{3}{*}{$\begin{array}{l}\text { Textual } \\
\text { meaning: } \\
\text { Mode }\end{array}$} & 10. To explain construct conjunctions & 0 & 0 & 0 & 0 & 0 & 0 & 1 \\
\hline & & $\begin{array}{l}\text { 11. To explain demonstrative } \\
\text { pronouns such as that and this }\end{array}$ & 0 & 0 & 0 & 0 & 0 & 0 & 0 \\
\hline & & $\begin{array}{l}\text { 12. To use appropriate thematic ties } \\
\text { and referential links to extend genre }\end{array}$ & 0 & 0 & 0 & 0 & 0 & 0 & 0 \\
\hline
\end{tabular}

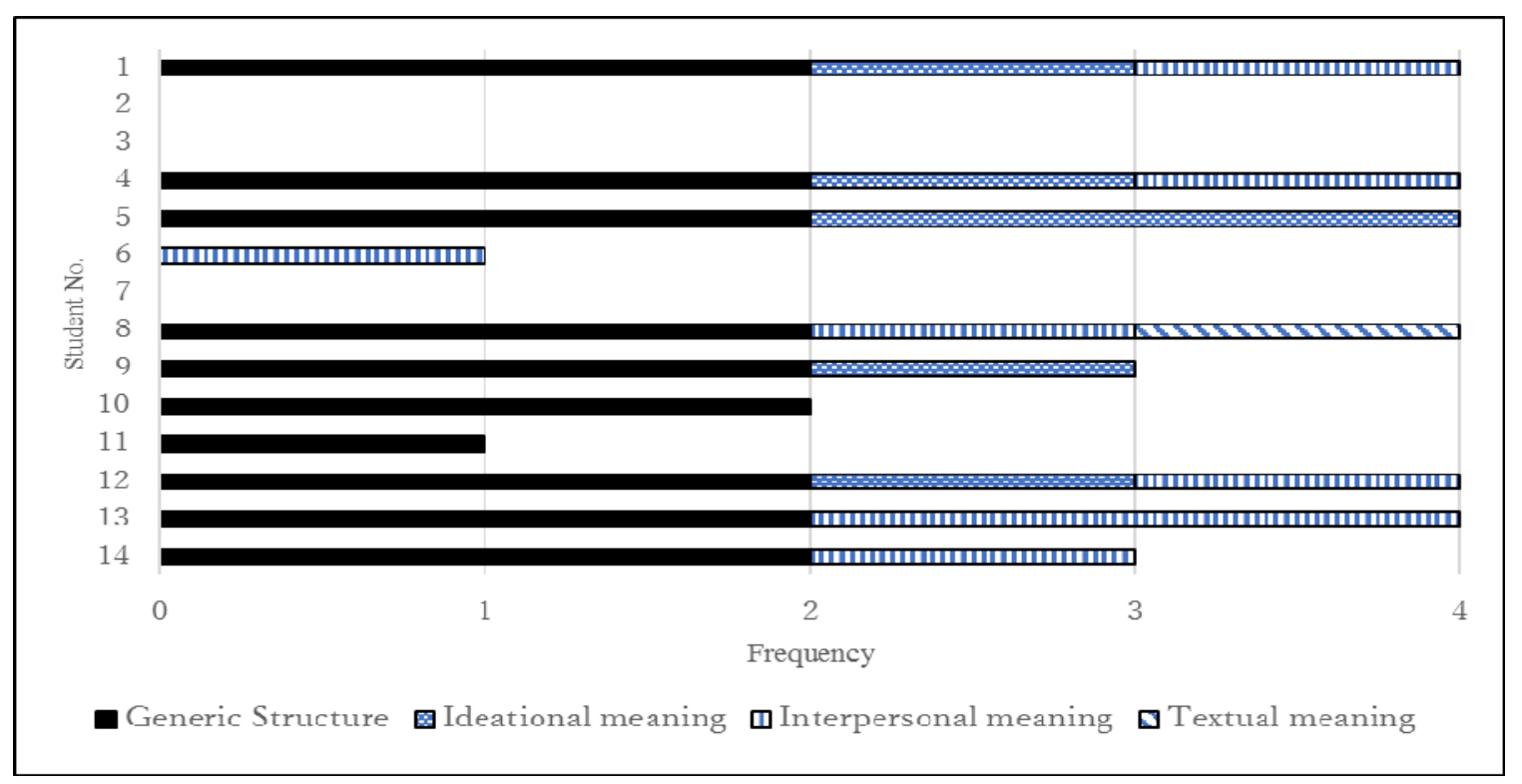

Figure 3. Generic structure and language features: results of 12-criteria assessment (individuals) 


\section{Discussion}

This study assessed how Japanese EFL undergraduates' awareness of generic structure, language features, and their lexicogrammatical choices in writing discussion essays changed during a single-semester course. In addition, a new methodology of teaching writing in an EFL context in Japan was explored using the SFL genre-based approach to language learning in order to test the methodology's effectiveness in a Japanese context.

In Phase 1, a pre-survey was administered to assess how well the students could write a discussion essay without detailed instruction, and no subsequent peer essay genre analysis was carried out. The results demonstrate a correlation between the survey statements regarding understanding of lexicogrammar in the introduction, body, and conclusion of the target genre and "I was particularly good at writing the body section of the last essay." A post-survey was administered after the instructional genre writing lesson, in accordance with Feez's (2002) genre teaching and learning cycle and peer analysis. The post-survey processes revealed no correlation between I14 (involving interaction with peer students and mutual instruction, "My ability to write discussion genre essays was improved through peer interactions and peer analysis") and the other items. The first hypothesis formulated to explain this is that "When the students participated in the peer essay genre analysis task, they were unable to identify its effectiveness." However, in the reflection on the peer essay genre analysis, Student 6 wrote:

"I suppose it is only to be expected, but I discovered that what I wrote was different. When I translated it into Japanese, the meaning was the same, but the words used were different and the subjects of the sentences were different. I also noted that the structure of the essay, particularly the order of opinions for or against in the second and third paragraphs, also differed from person to person. I alternated the supporting and opposing arguments, so that the third and fourth paragraphs would not have the same topic, but my two peers wrote differently. Probably, to avoid confusing the reader, they thought they would continue to write the same opinion in the third and fourth paragraphs, to place more emphasis on the conclusion (extracted from the student 6's self-reflection sheet)".

The content of this analysis suggests that it is difficult to prove categorically that the statement "My ability to write discussion genre essays was improved through peer interactions and peer analysis" is invalid.

We analyzed some of the items that revealed a statistically significant correlation only among the post-survey data analysis. The survey items were first divided into four groups. The first group concerned the relationship between "I know how to write discussion essays" and "I am particularly good at writing specific sections." In examining the combinations of "A) I know the discussion genre" and "I am good at the body section," I1 ("I am familiar with discussion writing in general") and I10 ("I am very good at writing the body section of discussion essays") did not reveal a high correlation in the pre-survey analysis $(r=0.46)$, but it did for the post-survey $(r$ $=.601$ ). For the second group, regarding the combinations of "B) I know the discussion genre" and "because I attended classes," we found a low correlation between I1 ("I am familiar with discussion writing in general") and I15 ("I improved my writing skills by attending writing and communication courses: writing") for the pre-survey $(r=0.36)$ but a high correlation for the post-survey $(r=.782)$.

The third group included combinations of "C) I know how to write an introduction" and "I am good at writing discussion essays." Here, I2 ("I completely understand how to write the introduction of the final essay") and I8 ("I am very good at writing discussion essays") reflected a relatively high correlation for the post survey ( $r$ $=.622$ ). Finally, the fourth group combined items from "D) I understand how to write the second and third paragraphs" and "I understand the linguistic features of introduction and body." This result implies the presence of some type of relationship between knowing ("understanding") the structure and the linguistic features of the target genre essay and having confidence in one's own writing skills ("feeling good at writing"). A possible explanation for this is that students who had previously taken genre-based approach language learning classes based on the teaching and learning cycle described herein had experience in writing discussion essays and were thus able to analyze the essays of their peers. This was confirmed by the positive correlation between I15 and I18 $(r=.543)$.

An in-depth, qualitative analysis sheet (self-reflection sheet) was used to analyze the students' meaning-making choices, demonstrated by how much they had improved in their genre awareness. Increasing the students' awareness of lexicogrammatical concepts such as experiential meaning and textual meaning was challenging for the teacher in this study, although most of the students understood the generic structure of the target genre. All of the lexicogrammatical features of the discussion essays were explained during the lessons; therefore, the participants in this study had some exposure to these language features prior to completing the timed essay and the self-reflection exercise. However, the students tended to focus on particular language features such as modal verbs while neglecting lexicogrammatical elements such as fixed phrases to express their opinion or modality (e.g., it is possible that and it is certain that), and many of them explained constructive conjunctions in their 
self-reflection analysis sheets. One of the reasons that the students were less aware of these lexicogrammatical concepts (both textual meaning and experiential learning) was because they lacked adequate experience to know how to use the target generic texts during the lessons. In other words, completing such a task requires using systemic methods such as the SFL genre-based approach to learning and long-term educational scaffolding to enable EFL students to develop their understanding of grammar (Williams, 2000; Mickan \& Lopez, 2017). To solve these problems, it is important to create additional tasks that involve students and provide them with sufficient exposure to target genre texts when modeling and deconstructing essays, in accordance with Feez's (2002) teaching and learning cycle.

\section{Acknowledgments}

This research was supported by Grant-in-Aid for Young Scientists (B) Grant Number JP16K16891 from the Japan Society for the Promotion of Science. I would like to thank the two anonymous reviewers for their invaluable comments and suggestions. Finally, I would like to acknowledge Dr. Peter Mickan (The University of Adelaide), whose thoughtful comments and feedback significantly improved the manuscript.

\section{References}

Abbaszadeh, Z. (2013). Genre-based approach and second language syllabus design. Procedia, 84, 1879-1884. https://doi.org/10.1016/j.sbspro.2013.07.052

Belcher, D. (2004). Trends in teaching English for specific purposes. Annual Review of Applied Linguistics, 24, 165-186. https://doi.org/10.1017/S026719050400008X

Browne, C. M., \& Wada, M. (1998). Current issues in high school English teaching in Japan: An exploratory survey. Language Culture and Curriculum, 11(1), 97-112. https://doi.org/10.1080/07908319808666543

Burns, A., Joyce, H., \& Gollin, S. (1996). "I see what you mean": Using spoken discourse in the classroom: A handbookfor teachers. National Centre for English Language Teaching and Research, Macquarie University, Sydney, New South Wales, Australia. Retrieved from http://www.ameprc.mq.edu.au/docs/research_reports/I_see_what_U_mean.pdf

Chen, Y. S., \& Su, S. W. (2012). A genre-based approach to teaching EFL summary writing. ELT Journal, 66, 184-192. https://doi.org/10.1093/elt/ccr061

Deng, X., Yang, Y., \& Varaprasad, C. (2014). Thesis writing course: Students' perceptions and attitudes toward the impact of the course on their thesis writing knowledge and skills. Journal of the Scholarship of Teaching and Learning, 4(3), 180-191. Retrieved from http://www.ajsotl.edu.sg/article/thesis-writing-course-students-perceptions-and-attitudes-toward-the-impactof-the-course-on-their-thesis-writing-knowledge-and-skills/

Feez, S. (2002). Heritage and innovation in second language education. In A. M. Johns (Ed.), Genre in the classroom: Multiple perspectives (pp. 43-69). Mahwah, NJ: Lawrence Erlbaum Associates.

Flower, L., \& Hayes, J. R. (1981). A cognitive process theory of writing. College Composition and Communication, 32(4), 365-387. https://doi.org/10.2307/356600

Halliday, M. A. K., \& Hasan, R. (1989). Language, context, and text: Aspects of language in a social-semiotic perspective. Oxford: Oxford University Press.

Halliday, M. A. K. (1994). Spoken and written modes of meaning. In D. Graddol, \& O. Boyd-Barrett (Eds.), Media Texts: Authors and Readers (pp. 51-73). Clevedon, UK: Multilingual Matters / Open University.

Halliday, M., Matthiessen, C. M., \& Matthiessen, C. (2014). An introduction to functional grammar. Routledge.

Hisaoka, T. (2012). Assessing EFL writing: Meaningful innovations through SFL. In T. Muller, S. Herder, J. Adamson, \& P. S. Brown (Eds.), Innovating EFL teaching in Asia (pp. 253-266). London: Palgrave Macmillan. https://doi.org/10.1057/9780230347823_20

Hodgson-Drysdale, T. (2013). Teaching writing informed by systemic functional linguistics: "I never would have thought of doing that..." (Doctoral dissertation). Retrieved from ERIC (ED558321).

Hyland, K. (2004). Disciplinary discourses, Michigan classics ed.: Social interactions in academic writing. Michigan: University of Michigan Press. https://doi.org/10.3998/mpub.6719

Hyland, K. (2007). Genre pedagogy: Language, literacy and L2 writing instruction. Journal of Second Language Writing, 16(3), 148-164. https://doi.org/10.1016/j.jslw.2007.07.005

Jordan, R. R. (1997). English for academic purposes: A guide and resource book for teachers. Cambridge: 
Cambridge University Press. https://doi.org/10.1017/CBO9780511733062

Knapp, P., \& Watkins, M. (2005). Genre, text, grammar: Technologies for teaching and assessing writing. UNSW Press.

Lingzhu, J. (2009). Genre-based approach for teaching English factual writing. HLT Magazine, 11(2), Retrieved from http://www.hltmag.co.uk/apr09/mart02.htm

Lirola, M. M. (2010). How to apply SFL in classroom practice: An example in bilingual education programs in the USA. The Buckingham Journal of Language and Linguistics, 3, 205-219.

Martin, J. R. (2001). A context for genre: Modelling social processes in functional linguistics. In J. de Villiers \& R. J. Stainton (Eds.), Communication in Linguistics (pp. 1-41). Toronto: Editions du GREF.

Martin, J. R. (2009). Genre and language learning: A social semiotic perspective. Linguistics and Education, 20(1), 10-21. https://doi.org/10.1016/j.linged.2009.01.003

Martin, J. R., \& Rothery, J. (1980). Writing project report 1. (Working Papers in Linguistics No. 1). Sydney: University of Sydney, Department of Linguistics.

Matsumoto, M. (2015). Formal English education in Japan: What causes "unsuccessful" English language learning? In L. T. Wong \& A. D. Jhaveri (Eds.), English language education in a global world: Practices, issues and challenges (pp. 307-315). New York: Nova Science Publishers.

McKinley, J. (2010). English language writing centres in Japanese universities: What do students really need? Self-Access Learning Journal, 1(1), 17-31. Retrieved from https://sisaljournal.org/archives/jun10/mckinley/

Mickan, P. (2013). Language curriculum design and socialisation. Bristol: Multilingual Matters.

Mickan, P., \& Lopez, E. (Eds.). (2017). Text-based research and teaching: A social semiotic perspective on language in use. London: Springer. https://doi.org/10.1057/978-1-137-59849-3

Nagao, A. (2017). Longitudinal study of EFL students using the systemic functional linguistics method. International Education Studies, 10(11), 47-62. https://doi.org/10.5539/ies.v10n11p47

Nishijo, M. (2017). Interpersonal lexico-grammatical analysis in teaching spoken discourse of English for football coaching. Ritsumeikan University Studies in Language and Culture, 28(4), 245-268.

Price, L., \& Price, J. (2002). Why genres matter. Hot text. (pp. 272-279). Berkeley, CA: New Riders. http://www.webwritingthatworks.com/HT03genres.pdf

Rajagopalan, U. M., \& Jie, S. (2016). Adopting a SFL-oriented approach for evaluating genre-based academic abstracts of EST undergraduate students in Japan. Paper presented at the 2016 International Conference on Advanced Mechatronic Systems, Melbourne, Australia, November 30-December 3, 2016. https://doi.org/10.1109/ICAMechS.2016.7813501

Rose, D. (2012). Genre in the Sydney school. In J. P. Gee, \& M. Handford (Eds.), The Routledge Handbook of Discourse Analysis, (pp. 209-225). London: Routledge.

Schleppegrell, M. J. (2004). The language of schooling: A functional linguistics perspective. New York: Routledge. https://doi.org/10.1017/S0047404504263059

Silva, T. (1990). Second language composition instruction: Developments, issues, and directions in ESL. Second language writing: Research insights for the classroom, 11-23. https://doi.org/10.1017/CBO9781139524551.005

Steiner, E. (1997). Systemic functional linguistics and its application to foreign language teaching. Estudios de Lingüistica Aplicada, 26, 15-27.

Troyan, F. J. (2013). Investigating a genre-based approach to writing in an elementary Spanish program. (Doctoral dissertation, University of Pittsburgh). Retrieved from http://d-scholarship.pitt.edu/id/eprint/18632

UNSW Department of School Education. (1989). The discussion genre: Language and social power. Metropolitan East Disadvantaged School Program Erskinerville, UNSW: Australia. Retrieved from https://educationalsemiotics.files.wordpress.com/2012/11/tfw_discussion_language_social_power.pdf

Watanabe, H. (2016). Genre analysis of writing tasks in Japanese university entrance examinations. Language Testing in Asia, 6(1), 4. https://doi.org/10.1186/s40468-016-0026-8

Yasuda, S. (2011). Genre-based tasks in foreign language writing: Developing writers' genre awareness, linguistic knowledge, and writing competence. Journal of Second Language Writing, 20(2), 111-133. 
https://doi.org/10.1016/j.jslw.2011.03.001

Yasuda, S. (2015). Exploring changes in FL writers' meaning-making choices in summary writing: A systemic functional approach. Journal of Second Language Writing, 27, 105-121. https://doi.org/10.1016/j.jslw.2014.09.008

Yoshihara, M. (2004). America no daigakuinn de seikou suruhouhou; How to success at graduate schools in America [in Japanese]. Tokyo: Chyuokouronshinshiya.

\section{Copyrights}

Copyright for this article is retained by the author(s), with first publication rights granted to the journal.

This is an open-access article distributed under the terms and conditions of the Creative Commons Attribution license (http://creativecommons.org/licenses/by/4.0/). 